\title{
SUPLEMENTASI ASAM LEMAK TERPROTEKSI DALAM RANSUM TERHADAP PERFORMANS AYAM KAMPUNG
}

\author{
Salomina Sambolinggi ${ }^{1)}$, Andi Murlina Tasse ${ }^{2)}$ dan Rahim Aka ${ }^{2)}$ \\ ${ }^{1)}$ Alumnus Fakultas Peternakan UHO \\ ${ }^{2)}$ Staf Pengajar Fakultas Peternakan UHO \\ *e-mail : andimurlinatasse@gmail.com
}

\begin{abstract}
ABSTRAK
Penelitian ini bertujuan untuk mengetahui penampilan produksi ayam kampung umur 10 minggu yang diberi ransum dengan suplementasi asam lemak terproteksi asam lemak terproteksi. Penelitian ini menggunakan 48 ekor ayam kampung yang dibagi ke dalam 12 plot kandang. Penelitian ini terdiri atas 3 perlakuan $(\mathrm{P} 0=$ ransum komersial $100 \%, \mathrm{P} 1=$ ransum komersial + campuran garam karboksilat kering 3\%, P2= ransum komersial + hidrolisat minyak sayur 3\%), dan 4 ulangan. Rataan konsumsi ransum 53,52 $\pm 3,96(\mathrm{P} 0), 38,86 \pm 5,12(\mathrm{PI})$ dan 50,72 \pm 6,41 (P2), pertambahan bobot badan 17,41 $\pm 4,80(\mathrm{P} 0), 18,89 \pm 2,77(\mathrm{PI})$, dan 16,22 $\pm 1,29(\mathrm{P} 2)$, konversi ransum 6,11 $\pm 1,46(\mathrm{P} 0)$, 3,92 $\pm 1,06(\mathrm{PI})$, dan 5,71 $\pm 1,09(\mathrm{P} 2)$. Analisis data menggunakan sidik ragam dilanjutkan dengan uji Kontras Ortogonal. Hasil penelitian menunjukkan bahwa suplementasi asam lemak terproteksi dalam ransum berpengaruh tidak nyata $(P>0,05)$ terhadap konsumsi ransum, pertambahan bobot badan dan konversi ransum ayam kampung umur 10 minggu. Kesimpulan bahwa (1) pemberian ransum dengan suplementasi asam lemak terproteksi 3\% CGKK (Campuran garam karboksilat kering) pada ayam kampung selama 3 minggu cenderung meningkatkan konsumsi bahan kering dan pertambahan bobot badan tetapi menurunkan konversi ransum dan (2) pemeberian ransum dengan suplementasi asam lemak terproteksi 3\% HMS (Hidrolisat minyak sayur) pada ayam kampung selama 3 minggu cenderung meningkatkan konsumsi bahan kering, pertambahan bobot badan dan konversi ransum.
\end{abstract}

Kata kunci: Suplementasi, Asam Lemak Terproteksi dan Performans Ayam Kampung

\begin{abstract}
The research was aimed to know to effect of supplementation of protected fatty acid in ratiaon on performance local chiken used 48 chikens which divided in 12 henhouse plots, with the research 3 treatments $(\mathrm{T} 0=$ commercial ration $100 \%$. $\mathrm{T} 1=$ commercial ration $+3 \%$ dry carboxy late salt mixed $(\mathrm{DCM}), \mathrm{T} 2=$ commercial ration $+3 \%$ coconut oil hydrolisate) and 4 replications. Daily feed intake $(\mathrm{T} 0=53,52 \pm 3,90, \mathrm{~T} 1=38,86 \pm 5,12$, $\mathrm{T} 250,72 \pm 6,41)$, gain $(\mathrm{T} 0=17,41 \pm 4,80, \mathrm{~T} 1=18,89 \pm 2,77, \mathrm{~T} 2=$ $16,22 \pm 1,22)$, and feed conversion $(\mathrm{T} 0=6,11 \pm 1,29, \mathrm{~T} 1=3,92 \pm 1,06, \mathrm{~T} 2=5,71 \pm 1,09)$ of local chikenThe data analysis used ANOVA continued by Orthogonal Contrast test. The study result showed that effect of supplementation of protected fatty acid 3\% DCM and 3\% $\mathrm{COH}$ in ratiaons were non significant different on. (1) The conclusion that supplementation of $3 \%$ DCM in ration for 3 weeks feeding on local chickens tend to increase daily feed intake, gain but decrease feed conversion. (2) The conclusion that supplementation of $3 \% \mathrm{COH}$ in ration for 3 weeks feeding on local chickens tend to increase daily feed intake, gain and feed conversion.
\end{abstract}

Keyword : Protected fatty acid supplementation and Performance of local chicken

\footnotetext{
${ }^{*}$ Corresponding authors
} 


\section{PENDAHULUAN}

Selera konsumen terhadap ayam kampung sangat tinggi, yang ditimbulkan dengan pertumbuhan populasi dan permintaan ayam kampung yang semakin meningkat dari tahun ke tahun (Bakrie et al., 2003). Tahun 2001 hingga tahun 2005 terjadi peningkatan produktivitas ayam kampung sebanyak $45 \%$, dan pada tahun 2005 hingga tahun 2009 konsumsi ayam kampung dari 1,49 juta ton meningkat menjadi 1,52 juta ton (Aman, 2011). Kenyataan ini perlu dukungan ketersedian pakan yang dapat mendukung produktivitas ayam kampung.

Peningkatan produktivitas ternak dapat ditingkatkan melalui perbaikan pakan diantaranya suplementasi asam lemak terproteksi. Menurut Joseph (2007), suplementasi asam lemak terproteksi seperti sabun kalsium sebagai sumber energi dalam pakan ternak ruminansia dapat meningkatkan produksi daging. Selanjutnya Tasse (2010), penambahan campuran garam karboksilat dan metil ester kering dalam ransum sapi perah dapat memperbaiki tampilan asam lemak dan produksi susu sapi. Hal ini diperkuat dengan penelitian terakhir oleh Yurleni et al., (2013), bahwa suplementasi asam lemak terproteksi campuran garam karboksilat kering (CGKK) dalam pakan dapat memperbaiki kualitas daging dan pertambahan bobot badan kerbau rawa.

Perbaikan pakan dan introduksi suplemen merupakan salah satu cara yang banyak digunakan. Menurut Coetzee dan Hoffman (2002) diet asam lemak akan diserap oleh hewan monogastrik dan didepositkan ke jaringan tubuhnya tanpa ada perubahan yang signifikan. Hasil penelitian Coetzee dan Hoffman (2002) menyatakan bahwa diet asam lemak pada hewan monogastrik akan diserap dan didepositkan ke jaringan tubuhnya tanpa ada perubahan yang signifikan. Hal ini dianggap potensial untuk melakukan manipulasi profil asam lemak pada jaringan tubuh unggas yang diberikan melalui pakan.
Penggunaan asam lemak terproteksi dalam ransum ayam kampung belum banyak terpublikasi dalam laporan hasil penelitian baik nasional maupun internasional. Oleh karena itu penelitian perlu dilakukan untuk melihat pengaruh suplementasi asam lemak terproteksi terhadap performans ayam kampung.

\section{MATERI DAN METODE}

\section{A. Lokasi dan Waktu Penelitian}

Penelitian ini dilaksanakan selama 2 bulan dari Desember sampai Januari 2014. Penelitian dibagi dalam 2 tahap yaitu tahap awal pemeliharaan untuk pembiasaan pakan pada ayam kampung umur 1-4 minggu dan tahap pengambilan data ayam kampung umur 5-10 minggu. Penelitian bertempat di Unit Kandang Unggas Laboratorium Lapangan dan Laboratorium Nutrisi dan Teknologi Pakan Fakultas Peternakan Universitas Halu Oleo, Kendari.

\section{B. Prosedur Penelitian}

\section{Bahan}

Bahan yang digunakan untuk penelitian terdiri atas ayam kampung 48 ekor, ransum komersil BP-11, limbah ikan tuna (kepala, ekor, tulang dan isi perut), sagu, asam Khlorida, potasium hidroksida, $\mathrm{NaCl}$, tawalohok (Canarium sp.), minyak sayur

Alat lain yang digunakan yaitu timbangan ditigal (untuk menimbang bobot badan ayam,dan bahan pakan), saringan untuk Peralatan yang digunakan dalam penelitian ini terdiri atas kandang ayam 12 unit kandang litter yang berukuran $1 \mathrm{x} 1 \mathrm{x}$ 0,6. Kandang masing-masing dilengkapi dengan tempat pakan dan tempat minum, serta lampu pijar 15 watt sebagai penghangat dan penerang. mengayak sagu, terpal untuk menjemur bahan pakan, karung untuk menampung bahan pakan, plastik hitam untuk menyimpan bahan pakan. Loyang sebagai wadah untuk mencampur pakan suplemen. 
Sedangkan analisis komposisi kimia, peralatan yang digunakan terdiri atas oven, tanur, cawan porselen, gegep, talang, labu kjehdahl, labu erlenmeyer, alat titrasi dan destilasi, kondensor, kertas saring, sintered glas dan desikator.

\section{Prosedur Penelitian}

1. Persiapan Penelitian

a. Pembuatan Campuran Garam
Karboksilat Kering (CGKK)

Pengolahan minyak ikan dilakukan untuk memudahkan penyampuran dengan pakan lain dalam konsentrat. Pembuatan campuran garam karboksilat kering dalam penelitian ini mengacu pada Tasse (2010). prinsip pembuatan campuran garam karboksilat kering (CGKK) yaitu hidrolisis minyak ikan dengan larutan asam. Minyak ikan yang digunakan untuk pembuatan CGKK berasal dari hasil pemasakan limbah pengolahan ikan berupa ekor, tulang, sirip dan kepala dengan daun tawalohok (1 bagian limbah pengolahan ikan, 7,51 bagian air, 0,3 bagian daun tawalohok).

Minyak ikan dicampur dengan larutan $\mathrm{HCl}$ lalu dikocok dan dipanaskan pada suhu $60^{\circ} \mathrm{C}$ selama 30 menit. Asam lemak bebas atau asam karboksilat yang dihasilkan dari hidrolisis asam minyak ikan, ditambah dengan larutan $\mathrm{KOH}$ dan diaduk, lalu disimpan pada suhu ruangan sehingga garam karboksilat yang terbentuk ke permukaan.

Air yang berada di bagian bawah dibuang, lalu garam karboksilat yang dihasilkan dicampur dengan sagu dengan perbandingan minyak ikan dengan sagu 1:5 $\mathrm{b} / \mathrm{b}$. Campuran sagu dan garam karboksilat (CSGK) dikeringkan dalam oven pada suhu $60^{\circ} \mathrm{C}$. Hasil pengeringan CSGK merupakan campuran garam karboksilat kering (CGKK) dapat dicampur dengan konsentrat. Penambahan garam karboksilat dengan sagu untuk memudahkan penyampuran dengan pakan lain. Pengeringan untuk menghindari kontaminasi campuran sagu dan garam karboksilat (CSGK) dengan mikroba.

\section{b. Pembuatan Hidrolisat Minyak Sayur (HMS)}

Pembuatan hidrolisat minyak sayur (HMS) mengacu pada Tasse (2010). Minyak sayur curah "Barco" yang diperoleh dari Pasar Kota di Kendari sebanyak 2 liter dicampur dengan $200 \mathrm{ml}$ larutan $\mathrm{KOH} 10 \%$ dan diaduk. Selanjutnya ditambah dengan $100 \mathrm{ml}$ larutan $\mathrm{NaCl} 10 \%$ dan diaduk. Hasil hidrolisis ditambah dengan sagu dengan perbandingan $1: 5 \mathrm{~b} / \mathrm{b}$ untuk memperoleh campuran sagu hidrolisat minyak (CSHM). CSHM dikeringkan dalam oven bersuhu $60^{\circ} \mathrm{C}$ untuk memperoleh hidrolisat minyak sayur.

\section{c. Penyusunan Ransum}

Ransum yang digunakan untuk penelitian terdiri atas ransum komersial dengan penambahan pakan suplemen asam lemak terproteksi dipersiapkan sesuai dengan rancangan perlakuan. Komposisi kimia ransum penelitian dapat dilihat pada Tabel 3.

Tabel 3. Komposisi Kimia Ransum Penelitian

\begin{tabular}{|c|c|c|c|}
\hline Petiandan & K. Air (6) & $\mathrm{K} L \mathrm{~L} \%$ & 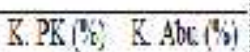 \\
\hline $\mathrm{PO}$ & 6 & 16 & 14,898 \\
\hline $\bar{p} i$ & 8 & 14 & 1634 \\
\hline $\bar{p} 2$ & $10^{\circ}$ & 22. & {$[5,00$} \\
\hline
\end{tabular}

Formulasi ransum yang digunakan pada penelitian yaitu :

$\mathrm{P0}=$ Konsentrat kontrol $(0 \%$ CGKK dan $0 \% \mathrm{H} \mathrm{MS}$ )

$\mathrm{P} 1=\mathrm{P} 0+3 \%$ campuran garam karboksilat kering (CGKK)

$\mathrm{P} 2=\mathrm{P} 0+3 \%$ hidrolisat minyak sayur (HMS) 


\section{d. Persiapan Kandang}

Kandang dan peralatannya disucihamakan terlebih dahulu, untuk mencegah kontaminasi mikroorganisme yang merugikan. Selanjutnya lantai kandang diisi serbuk gergaji sebagai lantai kandang.

\section{Pelaksanaan Penelitian}

\section{a. Pengacakan Perlakuan terhadap petak kandang}

Ayam kampung yang digunakan sebanyak 48 ekor. dibagi menjadi 12 petak kandang. Tiap petak diisi dengan 4 ekor ayam yang ditempatkan secara acak.

\section{b. Pemeliharaan Ayam Kampung}

Ayam kampung dipelihara sejak DOC sampai umur 10 minggu. Pakan dan minum diberikan secara adlibitum. Ransum (perlakuan) mulai diberikan pada umur 5 minggu. Pemberian pakan dilakukan setiap hari sebanyak 2 kali pada pukul 07.00 dan 17.00 WITA. Pengambilan data dilakukan selama 6 minggu pemeliharaan ayam kampung untuk melihat konsumsi ransum, pertambahan bobot badan dan konversi ransum.

\section{Rancangan Penelitian}

Rancangan penelitian yang digunakan adalah Rancangan Acak Lengkap dengan 3 perlakuan dan 4 ulangan, masingmasing ulangan terdiri atas 4 ekor ayam. Model matematika mengacu pada Hanafiah (2008) yaitu :

$$
Y i j=+\alpha i+\varepsilon i j
$$

Yij = Nilai pengamatan pada ulangan ke-i dan ulangan ke-j

$$
\begin{aligned}
\mu & =\text { Nilai rata-rata umum } \\
\alpha \mathrm{i} & =\text { Pengaruh perlakuan ke-i } \\
\varepsilon \mathrm{ij} & =\text { Pengaruh galat dan perlakuan }
\end{aligned}
$$

\section{E. Variabel Penelitian \\ Variabel yang diamati dalam penelitian ini adalah:}

a. Konsumsi Ransum
Konsumsi ransum merupakan selisih antara total pemberian dan sisa ransum yang diberikan setiap hari.

b. Pertambahan Bobot Badan

Pertambahan bobot badan dapat dihitung dengan mengurangi berat badan akhir dengan berat badan awal kemudian dibagi dengan lama pemeliharaan (Rasyaf, 2008).

c. Konversi ransum

Konversi ransum merupakan perbandingan antara konsumsi ransum dengan pertambahan bobot badan.

\section{F. Analisis Data}

Sidik ragam digunakan untuk mengetahui pengaruh perlakuan terhadap variabel penelitian (Hanafiah, 2008). Selanjutnya uji kontras orthogonal digunakan untuk melihat pengaruh antar perlakuan terhadap variabel penelitian.

\section{HASIL DAN PEMBAHASAN}

\section{A. Konsumsi Ransum}

Konsumsi ransum adalah jumlah ransum yang dikonsumsi setiap ekor selama penelitian. Konsumsi ransum menunjukkan jumlah makanan yang dimakan oleh ternak, untuk mencukupi kebutuhan hidup pokok dan produksi hewan tersebut (Rasyaf 2006). Rataan konsumsi ransum dengan suplementasi asam lemak terproteksi dapat dilihat pada Tabel 4. 
Tabel 4. Rataan Konsumsi Bahan Kering

\begin{tabular}{cccc}
\hline Lama pemberian & \multicolumn{3}{c}{ Konsumsi (g/ekor/hari) } \\
\cline { 2 - 4 }$($ minggu ke-i) & Kontrol & CGKK & HMS \\
\hline 1 & 47,79 & 34,22 & 39,98 \\
2 & 52,50 & 33,06 & 48,52 \\
3 & 52,52 & 36,80 & 50,89 \\
4 & 55,98 & 40,48 & 54,95 \\
5 & 52,73 & 46,48 & 51,04 \\
6 & 59,59 & 42,14 & 58,92 \\
Rataan & $53,52^{\mathrm{a}} \pm 3,96$ & $38,86^{\mathrm{a}} \pm 5,12$ & $50,72^{\mathrm{a}} \pm 6,41$
\end{tabular}

${ }^{\mathrm{a}}$ Superskrip yanga sama pada baris yang sama menunjukkan perlakuan berpengaruh tidak berbeda nyata pada tingkat kepercayaan 95\% (P>0,05).

Hasil sidik ragam menunjukkan pengaruh perlakuan tidak berbeda nyata terhadap konsumsi bahan kering $(\mathrm{P}>0,05)$. Artinya, pengaruh suplementasi asam lemak terproteksi (CGKK dan HMS) dalam ransum berpengaruh tidak nyata terhadap konsumsi bahan kering per hari. Hal ini menunjukkan konsumsi bahan kering yang dihasilkan ayam kampung dengan pemberian ransum suplementasi (CGKK dan HMS) tidak berbeda dengan tanpa suplementasi (Tabel 4).

Kisaran rataaan konsumsi bahan kering ransum dengan suplementasi asam lemak terproteksi $38,86 \quad-\quad 50,72$ gram/ekor/hari. Hasil penelitian ini lebih tinggi dibandingkan dengan Azina (2005), bahwa kisaran rataan konsumsi ransum pada ayam kampung fase starter 37,93-39,53 gram/hari. Sebelumnya, hasil penelitian ini lebih rendah dibandingkan dengan Gunawan dan Sulandari (2003), rataan konsumsi ayam kampung umur 6-13 minggu sekitar 64,62 gram/hari.

Banyak faktor yang mempengaruhi konsumsi ransum diantaranya besar, bangsa ayam, suhu lingkungan, jenis kelamin, aktivitas, kualitas pakan dan tahap/ periode produksi (Wahju, 2004). Selanjutnya bentuk, bau, rasa dan tekstur pakan (Tilman at al.,2005).

Tingkat konsumsi selama penelitian dapat dilihat pada Gambar 3

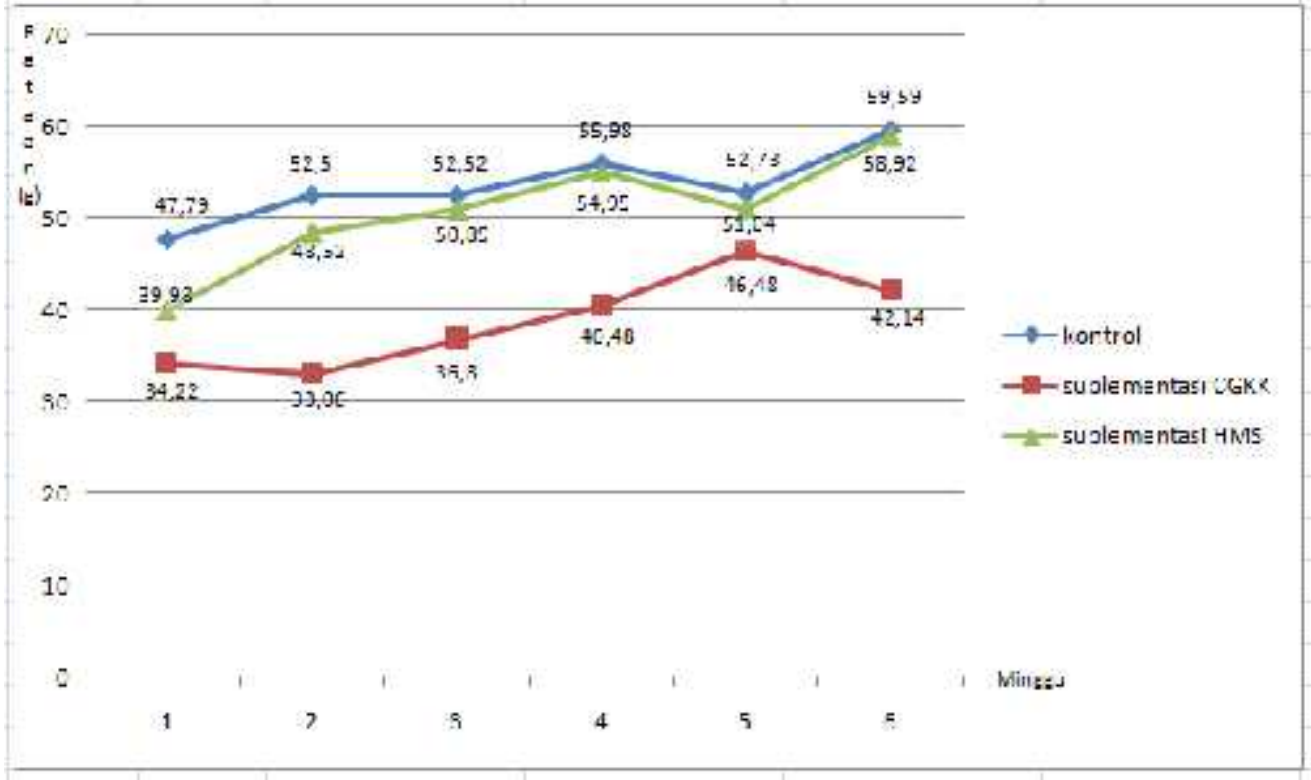

Gambar 3. Konsumsi bahan kering (g/ekor/hari) 
Pola rataan konsumsi bahan kering ransum per minggu selam 6 minggu pemberian pakan dapat dilihat pada Gambar 3. Rataan konsumsi bahan kering ransum tanpa suplementasi (kontrol) dan ransum dengan suplementasi HMS cenderung meningkat pada minggu ke - 1 sampai minggu ke - 4. Seperti halnya dengan rataan konsumsi bahan kering ransum dengan suplementasi CGKK meningkat pada minggu ke - 2 sampai minggu ke - 5 . Rataan konsumsi bahan kering ransum tanpa suplementasi dan ransum dengan suplementasi HMS menurun pada minggu ke - 5 tetapi meningkat pada minggu ke-6. Sebaliknya rataan konsumsi bahan kering ransum dengan suplementasi CGKK menurun pada minggu ke-6.

Pola rataan konsumsi bahan kering ransum dengan suplementasi CGKK lebih rendah dibandingkan dengan ransum tanpa suplementasi dan ransum dengan suplementasi HMS.
Hal ini disebabkan kadar protein lebih tinggi sehingga kandungan energi dalam ransum dengan suplementasi CGKK lebih tinggi dibandingkan dengan ransum tanpa suplementasi dan ransum dengan suplementasi HMS. Hasil penelitian ini didukung oleh Wahju (2004), bahwa tingkat konsumsi bahan kering ransum dipengaruhi oleh kandungan energi dalam ransum, dan NRC (1994), bahwa kadar serat kasar ransum yang rendah, dan kadar protein ransum yang tinggi menghasilkan kualitas pakan yang tinggi dan mempengaruhi konsumsi pakan.

\section{B. Pertambahan Bobot Badan}

Pertambahan bobot badan merupakan kenaikan bobot badan yang dicapai oleh seekor ternak selama periode tertentu (Rasyaf 2006). Rataan pertambahan bobot badan ayam kampung yang dipelihara secara intensif dapat dilihat pada Tabel 5

Tabel 5. Rataan Pertambahan Bobot Badan Ayam Kampung

\begin{tabular}{cccc}
\hline \multirow{2}{*}{$\begin{array}{c}\text { Lama } \\
\text { pemeliharaan } \\
\text { (minggu ke- })\end{array}$} & \multicolumn{3}{c}{ Pertambahan bobot badan (gram/ekor/hari) } \\
\cline { 2 - 4 } & Kontrol & CGKK & HMS \\
\hline 1 & 12,61 & 17,84 & 14,81 \\
2 & 13,67 & 17,53 & 17,92 \\
3 & 25,20 & 23,00 & 16,39 \\
4 & 20,58 & 19,77 & 17,31 \\
5 & 17,75 & 20,28 & 16,14 \\
6 & 14,67 & 14,92 & 14,75 \\
Rataan & $17,41^{\mathrm{a}} \pm 4,80$ & $18,89^{\mathrm{a}} \pm 2,77$ & $16,22^{\mathrm{a}} \pm 1,29$ \\
\hline
\end{tabular}

${ }^{a}$ Superskrip yanga sama pada baris yang sama menunjukkan perlakuan berpengaruh tidak berbeda nyata pada tingkat kepercayaan 95\% (P>0,05).

Analisis ragam menunjukkan pengaruh perlakuan tidak berbeda nyata terhadap PBB $(\mathrm{P}>0,05)$. Artinya, pengaruh suplementasi asam lemak terproteksi (CGKK dan HMS) berpengaruh tidak nyata terhadap PBB

Kisaran rataan $\mathrm{PBB}$ ayam kampung hasil pemberiam ransum tanpa dan dengan suplementasi CGKK dan HMS 16,22 18,89 gram/ekor/hari. Hasil penelitian ini lebih tinggi dibandingkan dengan Azina (2005), bahwa pertambahan bobot badan ayam kampung pada periode starter 9,17-
12.94 gram/hari. Perbedaan hasil-hasil penelitian ini disebabkan oleh kualitas ransum yang digunakan untuk pertumbuhan ayam kampung. Menurut Anang (2008), pada masa pertumbuhan terjadi pembelahan dan pertumbuhan sel yang tinggi sehingga masa pertumbuhan merupakan kunci awal untuk pencapaian bobot badan. Selanjutnya, faktor yang mempengaruhi PBB yaitu kualitas DOC, kondisi lingkungan, dan pakan yang baik. Laju PBB selama penelitian dapat dilihat pada Gambar 4. 


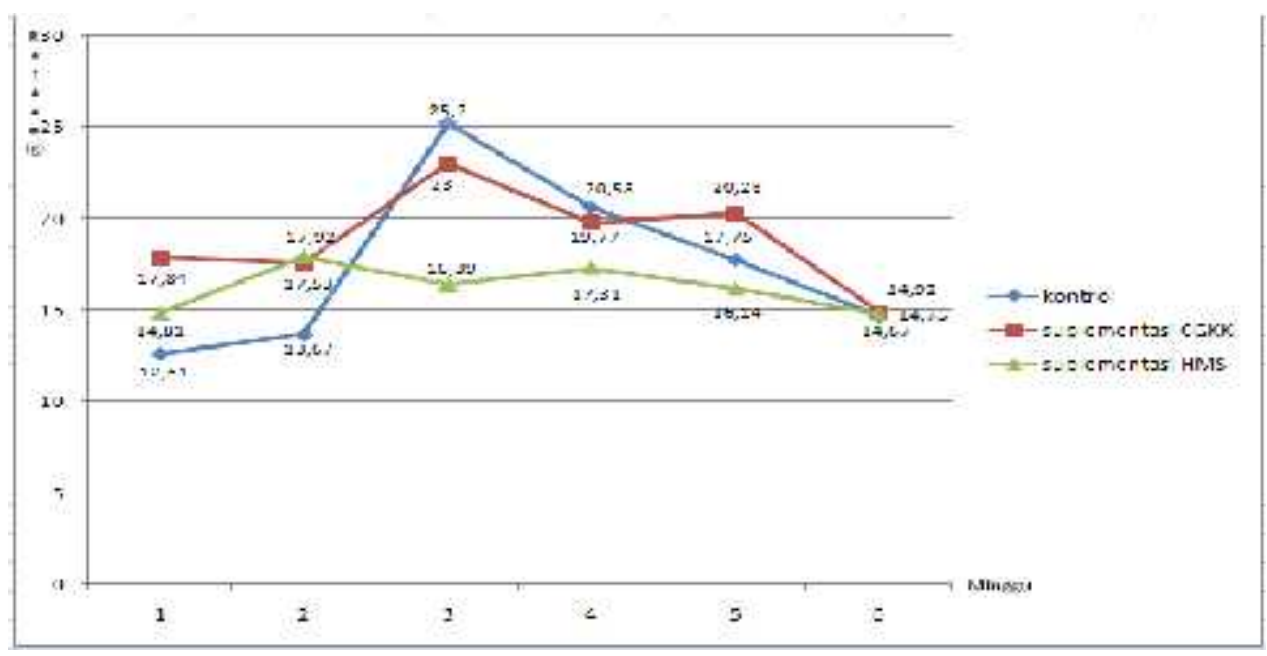

Gambar 4. Pertambahan bobot badan ayam kampung (g/ekor/hari)

Pola rataan pertambahan bobot badan per minggu pemberian pakan dapat dilihat pada Gambar 4. Laju pertambahan bobot badan ayam kampung dengan pemberian ransum tanpa atau dengan suplementasi CGKK dan HMS sangat beragam. Pertambahan bobot badan ayam dengan pemberian ransum tanpa dan dengan suplementasi CGKK menurun pada minggu ke- 2, ke - 4 dan sebaliknya pertambahan bobot badan ayam dengan pemberian ransum dengan suplementasi HMS meningkat pada minggu ke- 2 dan ke - 4 . Tetapi menurun pada minggu ke - 3 , ke - 5 sampai ke - 6 .

Hal ini menunjukkan rataan pertambahan tertinggi cenderung dicapai pada pemberian ransum tanpa suplementasi selama 3 minggu, dan pemberian ransum dengan suplementasi CGKK selama 3 minggu.
Pertambahan bobot badan ayam yang dihasilkan ketiga perlakuan hampir sama dan menurun pada minggu ke - 6. Sehingga pemotongan dilakukan pada minggu ke -6 .

\section{Konversi Ransum}

Konversi ransum merupakan rasio antara konsumsi ransum dangan pertambahan bobot badan yang diperoleh dalam kurun waktu tertentu. Semakin tinggi konversi ransum menunjukkan semakin banyak ransum yang dibutuhkan untuk meningkatkan bobot badan per satuan berat. Rataan konversi ransum ayam kampung dengan suplementasi asam lemak terproteksi dapat dilihat pada Tabel 6. Tabel 6 . Rataan Konversi Ransum Ayam Kampung

\begin{tabular}{cccc}
\hline $\begin{array}{l}\text { Lama pemberian } \\
\text { (minggu ke-i) }\end{array}$ & \multicolumn{3}{c}{ Konversi (gram/ekor/hari) } \\
\cline { 2 - 4 } & Kontrol & CGKK & HMS \\
\hline 1 & 7,07 & 3,51 & 4,45 \\
2 & 6,93 & 3,33 & 4,92 \\
3 & 3,72 & 2,80 & 5,50 \\
4 & 5,33 & 3,50 & 5,82 \\
5 & 5,87 & 4,70 & 5,97 \\
6 & 7,76 & 5,68 & 7,62 \\
Rataan & $6,11^{\mathrm{a}} \pm 1,46$ & $3,92^{\mathrm{a}} \pm 1,06$ & $5,71^{\mathrm{a}} \pm 1,09$ \\
\hline
\end{tabular}

${ }^{a}$ Superskrip yanga sama pada baris yang sama menunjukkan pengaruh perlakuan tidak berbeda nyata pada tingkat kepercayaan 95\% ( $\mathrm{P}>0,05)$. 
Hasil sidik ragam menunjukkan pengaruh perlakuan tidak berbeda nyata terhadap konversi ransum $(\mathrm{P}>0,05)$. Artinya, pengaruh suplementasi asam lemak terproteksi (CGKK dan HMS) berpengaruh tidak nyata terhadap konversi ransum.

Kisaran rataan konversi ransum dengan suplementasi asam lemak terptoksi 3,925,71. Hasil penelitian ini lebih rendah dibandingkan dengan hasil penelitian Gunawan dan Sulandari (2003), bahwa kisaran konversi ransum ayam kampung dengan pemberian probiotik yaitu $6,10-7$, 30. Perbedaan hasil penelitian ini berindikasi suplementasi asam lemak terproteksi lebih baik dalam penggunaan pakan dibandingkan dengan penggunaan probiotik pada ayam kampung. Banyak faktor yang mempengaruhi konsumsi ransum diantaranya imbuhan pakan, tipe pakan dan manajemen pemeliharaan (James 2004). Konversi ransum ayam kampung selama peneliti dapat dilihat pada Gambar 5

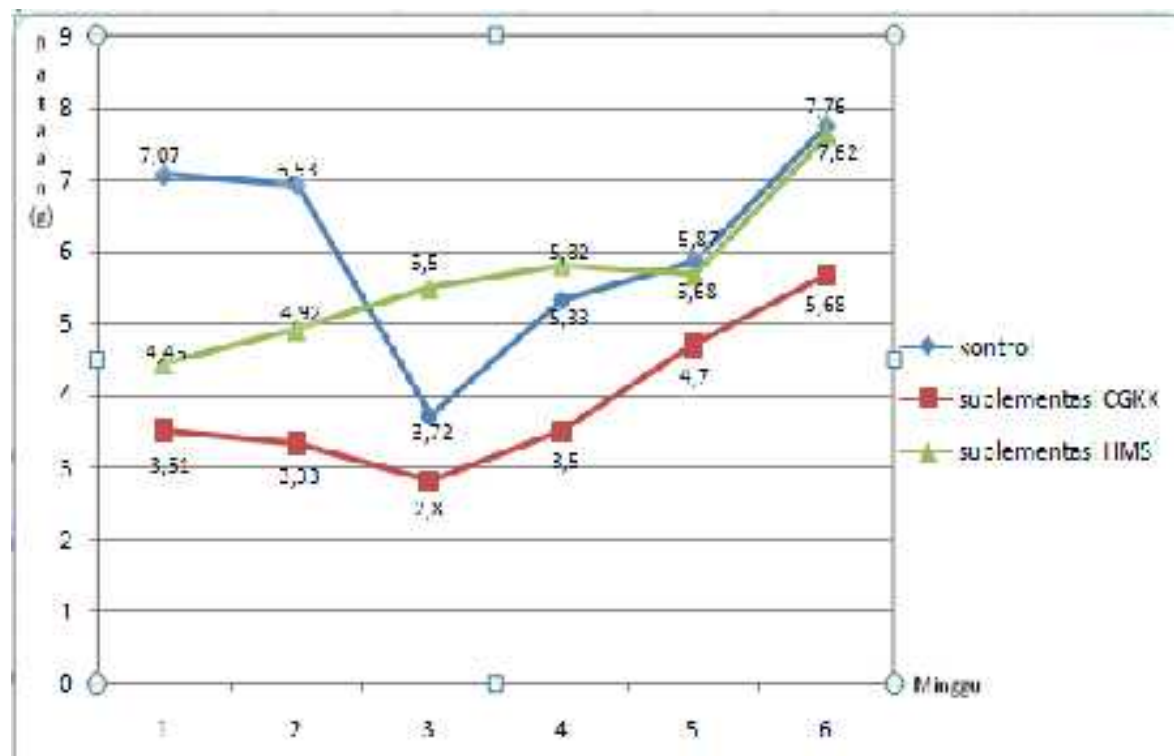

Konversi ransum ayam kampung

Pola rataan konversi ransum per minggu selama 6 minggu pemberian ransum dapat dilihat pada Gambar 5. Rataan konversi ransum dengan suplementasi CGKK dan HMS menurun pada minggu ke2 sampai minggu ke- 3, tetapi meningkat pada minggu ke- 4 sama dengan minggu ke6. Sebaliknya rataan konversi ransum tanpa suplemen asam lemak terproteksi meningkat pada minggu ke-2 sampai minggu ke- 6 . Rataan konversi ransum terendah diperoleh dari ransum tanpa dan dengan suplementasi CGKK pada minggu ke- 3 . Hal ini menunjukan penggunaan ransum dengan suplementasi CGKK paling baik diberikan selama 3 minggu. Menurut Mulyono (2006), konversi pakan menunjukkan seberapa banyak pakan yang dikonsumsi (gram) sudah menghasilkan bobot badan 1 kg selanjutnya, Kuotiningrum (2004), bahwa angka konversi pakan yang tinggi menunujukkan penggunaan pakan kurang efisien, dan semakin banyak ransum yang dibutuhkan untuk meningkatkan bobot badan persatuan berat. Kisaran konversi ini dapat menghasilkan bobot karkas 265,75 377. 00 gram dan presentase bobot karkas $56,76-63,21 \% \quad$ (Bintayani, 2014).

\section{KESIMPULAN}

Berdasarkan hasil penelitian ini maka disimpulkan bahwa

1. Pemberian ransum dengan suplementasi asam lemak terproteksi 3\% CGKK (Campuran garam karboksilat kering) pada ayam kampung selama 3 minggu 
cenderung meningkatkan konsumsi bahan kering dan pertambahan bobot badan tetapi menurunkan konversi ransum

2. Pemberian ransum dengan suplementasi asam lemak terproteksi 3\% HMS (Hidrolisat minya sayur) pada ayam kampung selama 3 minggu cenderung meningkatkan konsumsi bahan kering, pertambahan bobot badan dan konversi ransum.

\section{DAFTAR PUSTAKA}

Aman, Y. 2011. Ayam Kampung Unggul. Penerbit Penebar Swadaya. Jakarta

Anang, A. dan Suharyanto. 2008. Panen Ayam Kampung. Penebar Swadaya. Jakarta.

Aziana W. 2005. Pemberian Neobro dalam Ransum terhadap Penampilan Ayam Kampung Fase Starter. Skripsi. Universitas Halu Oleo, Kendari.

Bakrie, B. D. Andayani, M. Yanis, dan D. Zainuddin. 2003. Pengaruh Penambahan Jamu ke dalam Air Minum Terhadap Preferensi Konsumen dan Mutu Karkas Ayam Buras. hlm. 490-495. Prosiding Seminar Nasional Teknologi Peternakan dan Veteriner "Iptek untuk Meningkatkan Kesejahteraan Petani melalui Agribisnis Peternakan yang Berdaya Saing”. Bogor, 29-30 September 2003. Pusat Penelitian dan Pengembangan Peternakan, Bogor.

Joseph G. 2007. Suplementasi Sabun Kalsium Dalam Pakan Ternak Sebagai Sumber Energi Alternatif Untuk Meningkatkan Produksi Daging Yang Berkualitas. Disertasi. Bogor. Institut Pertania Bogor.
Rasyaf, M. 2006. Bahan Makanan Unggas. Edisi Revisi. Penerbar Swadaya, Jakarta.

2008. Panduan Beternak Ayam Pedaging. Penebar Swadaya. Jakarta.

Sartika, T. Dan S. Iskandar. 2007. Mengenal Plasma Nutfah Ayam Indonesia dan Pemanfaatannya. Buku. Edisi pertama. Balai Penelitian Ternak, Bogor.

Sulandari, S. M. S. A. zein, S. Paryanti dan T. Sartika. 2007. Taxonomi dan Asal Usul Ayam Domestikasi. Dalam buku: Keanekaragaman Sumber Daya Hayati Ayam Lokal Indonesia: Manfaat dan Potensi. K. Diwyant dan s.n. prijono (eds.). Lipi press. Hlm. 7-42.

Suprijatna, E. U. Atmomarsono. dan. R, Kartasudjana. 2005. Ilmu Dasar Ternak Unggas. Penebar Swadaya. Jakarta.

Tasse, A. M. 2010. Tampilan Asam Lemak dalam Susu Sapi Hasil Pemberian Ransum Mengandung Campuran Garam Karboksilat Atau Metil Ester Kering. Disertasi. Institut Pertanian Bogor. Bogor.

Yurleni, Priyanto2. R. Gurnadi. E. dan Wiryawan. K. G. 2013. Efektivitas Minyak Ikan Lemuru Terproteksi Terhadap Populasi Mikrob Rumen dan Fermentasinya pada Kerbau dan Sapi. Disertasi. Institut Pertanian Bogor, Bogor. 